\title{
TOWARDS OPTIMAL DESIGN OF ENERGY EFFICIENT BUILDINGS
}

\author{
R.R. GAJEWSKI ${ }^{1}$, T. KUŁAKOWSKI ${ }^{2}$
}

\begin{abstract}
Buildings consume half of all energy use and are also responsible for a similar proportion of carbon dioxide emission. The heat transfer across the building envelope - the shell of a house that separates the inside and outside - should generally be minimized. In the paper validation and verification based on Building Energy Simulation Test (BESTEST) of Energy3D computer code is presented. Next, computations performed by means of Energy 3D and Energy Plus for BESTEST building are compared. In the last part of the paper results for computations for real building are presented. Program Energy 3D proved to be an excellent tool for qualitative and quantitative analysis of buildings with respect to energy consumption.
\end{abstract}

Keywords: energy efficient buildings, simulation, verification, validation, FEM, FVM, FDM

\section{INTRODUCTION}

Buildings consume half of all energy use and are also responsible for a similar proportion of carbon dioxide emission. The heat transfer across the building envelope - the shell of a house that separates

\footnotetext{
${ }^{1}$ DSc., PhD., Eng., Warsaw University of Technology, Faculty of Civil Engineering, Al. Armii Ludowej 16, 00-637 Warsaw, Poland, e-mail: r.gajewski@il.pw.edu.pl

${ }^{2}$ MSc., Eng., Warsaw University of Technology, Faculty of Civil Engineering, Al. Armii Ludowej 16, 00-637 Warsaw, Poland, e-mail: t.kulakowski@il.pw.edu.pl
} 
the inside and outside - should generally be minimized. In the first part of twentieth century, calculations of the thermal response of buildings have made an assumption that the boundary conditions and the whole problem are static. Thus, a fictitious steady-state problem was defined in order to perform thermal energy calculations. Now building energy modelling is mainly based on Computational Fluid Dynamics (CFD) methods. In the paper validation and verification based on BESTEST by Energy3D computer code is presented. Program proved to be an excellent tool for qualitative and quantitative analysis of buildings. During the first part of the project [6] Energy 3D code was investigated as a tool which can be used to perform qualitative and quantitative analysis of building energy balance. In the second part of the project [7] results obtained with Energy3D code for BESTEST buildings located in Białystok and Wrocław - average daily energy consumption and monthly energy consumption - were compared with results from Energy Plus code. The last part of the project presented in this paper is devoted to calculations of real building dom $4 \mathrm{e}$ designed by Wienerberger.

\section{LITERATURE REVIEW}

An excellent review of different modelling methods for calculating energy balance in building is given by Underwood and Yik in their book [27]. Energy simulation in building design is presented by Clarke in [2]. Building performance simulation for design and operation are described in the monograph [11] edited by Hensen and Lambers. Review of different building simulation applications can be found in [1]. Practical approach to computational fluid dynamics, which is suitable for civil engineers, can be found in [26]. A practical guide to finite element methods for computational fluid dynamics is presented in [15]. All computer codes used for building energy simulations, especially these based on computational fluid dynamics, are very complicated. Their proper usage requires deep theoretical and practical knowledge. There are two computer codes - Energy2D and Energy3D created by Doctor Charles Xie which are very simple and user friendly. Both programs and their usage are described in a detailed way in [8], [30] and [31]. Matching building energy simulation models to measured data is getting more interest [3] during the last years. There are also many papers devoted to comparing measured and simulated building energy performance data [16], [17]. 


\section{THEORETICAL BACKGROUND OF BUILDING ENERGY}

The thermal performance of a building is represented by the efficiency with which it uses energy to maintain the thermal comfort for its occupants. In order to calculate this energy all ways of heat transfer are taken into account: thermal conduction, convection and radiation. In thermal conduction the rate of heat flow is governed by the following relationship:

$$
\frac{\Delta Q}{\Delta t}=-\lambda A \frac{\Delta T}{\Delta x}
$$

where $\Delta Q$ is the thermal energy change of the object within time period of $\Delta t, \Delta T$ is the temperature difference across a distance $\Delta x, \lambda$ is the thermal conductivity of the material and $A$ is the area.

This relation is also known as Fourier's law of thermal conduction in which we use the concept of heat flux $\Phi$.

$$
\Phi=-\lambda \frac{\Delta T}{\Delta x}
$$

In the process of convection thermal energy passes by a flow of fluid. Convective heat flux is estimated by simple formula

$$
\Phi=h\left(T-T_{\infty}\right)
$$

where $h$ is the convective heat transfer coefficient of a fluid, $T$ is the temperature of the surface and $T_{\infty}$ is the temperature of the fluid. This equation is known as Newton's law of cooling. In the radiation process the energy radiated by an object per unit time is proportional to the fourth power of the absolute temperature

$$
\Phi=\varepsilon \sigma T^{4}
$$


where $\sigma$ is the Stefan-Boltzmann constant, $\varepsilon$ is the emissivity of the object's material. This formula is known as Stefan-Boltzmann law. The heat transfer across the building envelope - the shell of a house that separates the inside and outside, should generally be minimized.

Solving Fourier's equation analytically in unsteady heat transfer problems is impossible with current state of the art, and because of that discrete methods are needed in simulations of building energy performance [5], [9]. The most common methods are e.g. a conduction transfer functions method, solving buildings in analogy to electrical circuits, control volume methods (CVM) [28] or finite elements methods (FEM) [19]. Depending on the purpose of calculations each of the approaches have several advantages and disadvantages, but basically the first two are mostly used in whole building calculation, while the last two are more common in analyses of particular elements or structures. Regardless of the method according to Lax's law if solution is stable and consistent discrete formulations should bring analyst closer to the exact solution when $\Delta \mathrm{x} \rightarrow 0$ and $\Delta \mathrm{t} \rightarrow 0$. While such way of finding a solution is obvious and required in scientific research, it is often impossible in commercial analysis of building energy performance due to a high complexity of domain, long time periods being analyzed (basic time period is one year, sometimes extended in order to provide reasonable dynamics of heat transfer), lack of meteorological data with the time step shorter than one hour and also lack of standards defining benchmarks for an exact solution and limited computational possibilities of computers. In subsequent chapters brief description of two discrete methods most commonly used in building energy balance calculations will be given, namely: a conduction transfer functions method as a solution of transient heat transfer in single structure and solution based on an electrical circuit analogy enabling whole building analysis.

\subsection{CONDUCTION TRANSFER FunCtions (CTF)}

The conduction transfer functions method is based on an idea of scaling energy transfer taking place in the modeled structure due to an unit load. It was first introduced by Mitalas and Stephenson in 1971 [25] and later described in [4]. Big advantage of this method is that once calculated, coefficients of functions allow easier analysis of heat fluxes taking place through the structure. The procedure of calculation CTF coefficients is as follows - let's take into consideration a single layered structure given in Figure 1. 


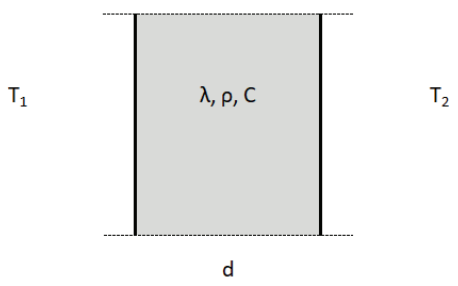

Fig. 1. Cross section of the analyzed structure.

Calculations performed for two cases - temperature raise and drop on internal and external surface (see Fig. 2) give variations of temperature on each surface due to a change on the opposite one.
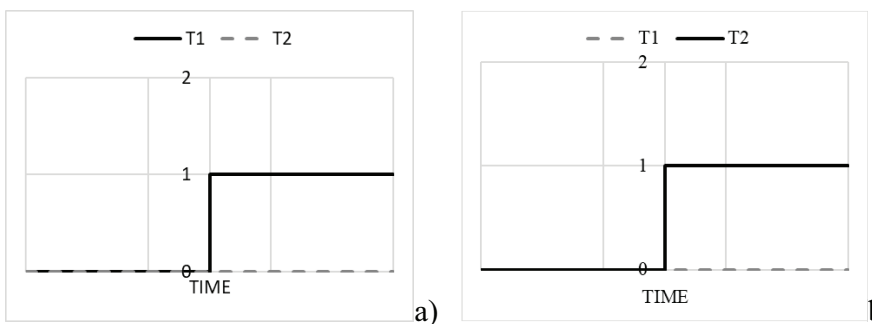

a)

b)

Fig. 2. a) Case of $\mathrm{T} 1$ temperature raise; b) Case of $\mathrm{T} 2$ temperature raise.

Transient heat transfer may be calculated using any available method. In a presented case Finite Difference Method (FDM) is used. The solution of presented problem are heat fluxes on both surfaces in both cases (temperature raise on internal and external surface). Figure 3 presents sample results for temperature raise on surface 1 .
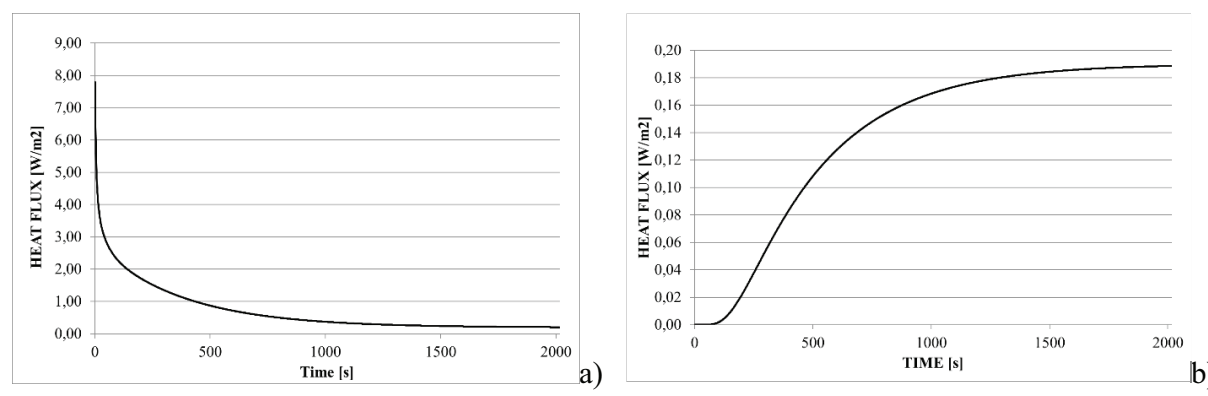

Fig. 3. Heat flux on surface 1 after temperature raise on: a) surface 1 b) surface 2 . 
Further analysis gives answer to the question how the structure is responding to temperature unit load presented in Figure 4.

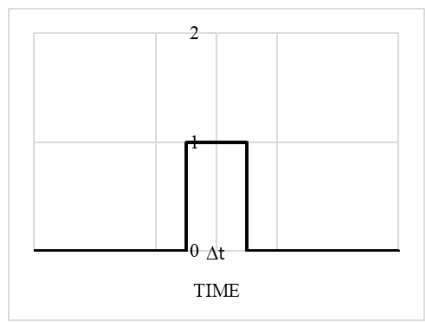

Fig. 4. Temperature unit load.

When coefficients of CTF functions are known, calculation of convolutions of transient temperature function and surface response functions gives a solution for heat fluxes on the outer and inner surfaces for any temperature function. Difference between heat flux on inner and outer surfaces gives an energy balance in any time step of a temperature function. Analysis is done once for each structure, and is repeated for each part of the building.

This method is widely used in building simulation software e.g. EnergyPlus, ESP-r and TRNSYS. Its biggest advantage is that having once calculated responses for unit temperature raise (or drop) on both surfaces of the structure, it may be easily scaled to any temperature change. Another advantage is that this method allows to apply very intuitive geometry declarations. In this method structures are declared as "box walls" - they keep all of their heat capacity features, but their cross sections are not used in further analysis. The whole method is based on the assumption that heat transfer parameters are independent of temperature - they are the same as for an unit load. It makes the method useless in analysis of structures with e.g. Phase Change Materials (PCM) layer or any other material changing its parameters. Also simple geometrical approach makes this method not applicable in more sophisticated analysis like e.g. thermal bridges, etc.

\subsection{SOLUTIONS OF BUILDING SIMULATIONS IN ANALOGY TO ELECTRICAL CIRCUITS}

Electrical circuits are a very intuitive way of imitating energy transfer. This method was used for the first time in 1958 by Robertson and Gross [22] and it is used in various building physics analysis. In building energy balance simulations analogy between heat or mass transfer is provided by replacing each type of structure or systems by corresponding electric devices, e.g. resistor, source or capacitor. Different software provide a different approach of modelling building. One of such methods is 
proposed by PN-EN 13790:2007 standard and it is also known as 5R1C method. In this approach system is divided into several groups - opaque structures, translucent structures, ventilation and gains. Each region is represented by electrical devices that would fit best in its characteristics (heat capacity, dynamism, etc.). Several papers treat on model extensions by additional resistors, representing e.g. Air Handling Unit [18], in order to improve its applicability in common problems. Such extended model involving additional resistor is then called 6R1C.

The method proposed by PN-EN 13790:2007 standard has several advantages - in particular it may be solved without iterative calculations. Moreover it allows to consider basic occupation schedules and to take into consideration heat transfer dynamics (alternative construction solutions may be compared). On the other hand all opaque structures are represented by one capacitor, which means that possibilities of this method in the area of different zones occupation or temperatures schedules are limited. Also heat gains are represented by one number, independently of zones. This makes this algorithm useless in modern analysis where the model is expected to be able not only to simulate complex phenomenon with the biggest accuracy, but also to incorporate data measured online to forecast building's energy consumption and adjust its settings basing on performed calculations.

\section{VERIFICATION AND VALIDATION}

In addition to all errors that can arise while performing numerical simulation there are also uncertainties due to improper modelling of physics or incorrect computational design. Verification and validation procedures are used in order to properly assess the quality of the solution. Both terms have distinctive definitions. As stated in [26] "verification can be defined as a process for assessing the numerical simulation uncertainty and when conditions permit, estimating the sign and magnitude of the numerical simulation error and the uncertainty in that estimated error. This procedure concerns primarily the input parameters used for geometry, initial conditions, and boundary conditions." On the other hand, as stated in [26] "validation can be defined as a process for assessing simulation model uncertainty by using benchmark experimental data and when, conditions permit, estimating the sign and magnitude of the simulation modelling error itself." This procedure simply means validating the calculations by establishing a range of physical conditions obtained from the calculations and by performing comparisons of the results from the CFD code with experiments that span that range of conditions.

Both processes were performed for Energy3D code in order to check the quality of models and results of simulations. From a validation perspective, comparative tests will show that Energy3D gives 
solutions that are reasonable compared to other energy simulation programs. Comparative testing is also useful for input debugging. Energy simulation programs have so many inputs and outputs that the results are often difficult to interpret. In order to compare results with these known from literature Building Energy Simulation Test (BESTEST) was used. It was described in many publications Henniger [10], Judkoff [12], Reddy [21], Judkoff [14] Judkoff [13] Woloszyn [29] Rode [23] and Soub [24]. Sample BESTEST building is shown in Fig. 5. The tests described in ANSI/ASHRAE Standard 140-2001, Standard Method of Test for the Evaluation of Building Energy Analysis Computer Programs (ANSI/ASHRAE 2001) were performed.

The basic test building 600 is a rectangular single zone ( $8 \mathrm{~m}$ wide $\times 6 \mathrm{~m}$ long $\times 2.7 \mathrm{~m}$ high) with no interior partitions and $12 \mathrm{~m}^{2}$ of windows on the south exposure (see Fig. 5). The building is of lightweight construction with characteristics as described below in Table 1.

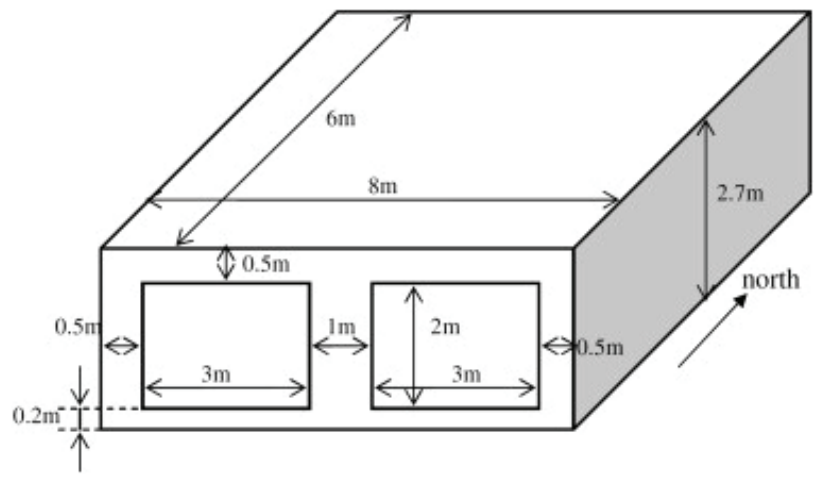

Fig. 5. BESTEST case building 600 .

Table 1. Wall Construction (light weight mass).

\begin{tabular}{|c|c|c|c|c|c|c|}
\hline Element & $\begin{array}{c}\mathbf{k} \\
{[\mathbf{W} / \mathbf{m K}]}\end{array}$ & $\begin{array}{c}\text { Thickness } \\
{[\mathbf{m}]}\end{array}$ & $\begin{array}{c}\mathbf{U} \\
{\left[\mathbf{W} / \mathbf{m}^{2} \mathbf{K}\right]}\end{array}$ & $\begin{array}{c}\mathbf{R} \\
{\left[\mathbf{m}^{\mathbf{2}} \mathbf{K} / \mathbf{W}\right]}\end{array}$ & $\begin{array}{c}\mathbf{D e n s i t y} \\
{\left[\mathbf{k g} / \mathbf{m}^{3}\right]}\end{array}$ & $\begin{array}{c}\mathbf{c}_{\mathbf{p}} \\
{[\mathbf{J} / \mathbf{k g K}]}\end{array}$ \\
\hline Int. Surface Coeff. & & & 8.290 & 0.121 & & \\
\hline Plasterboard & 0.160 & 0.012 & 13.333 & 0.075 & 950 & 840 \\
\hline Fiberglass Quilt & 0.040 & 0.066 & 0.606 & 1.650 & 12 & 840 \\
\hline Wood Siding & 0.140 & 0.009 & 15.556 & 0.064 & 530 & 900 \\
\hline Ext. Surface Coeff. & & & 29.300 & 0.034 & & \\
\hline Overall, air-to-air & & & 0.514 & 1.944 & & \\
\hline
\end{tabular}


Other data for the BESTEST case building 600 are as follows:

- Infiltration: 0.5 air change/hour.

- Internal Load: $200 \mathrm{~W}$ continuous, $60 \%$ radiative, $40 \%$ convective, $100 \%$ sensible.

- Mechanical System: 100\% convective air system, 100\% efficient with no duct losses and no capacity limitation, no latent heat extraction, non-proportional-type dual setpoint thermostat with dead band, heating $<20^{\circ} \mathrm{C}$, cooling $>27^{\circ} \mathrm{C}$.

- Soil Temperature: $10^{\circ} \mathrm{C}$ continuous.

Charts comparing Energy3D results obtained for Denver Colorado with other whole building energy simulation programs are shown in Fig. 6. More results can be found in B.Sc. thesis prepared by Pieniążek [20]. The biggest differences are for buildings 600 and 610, so the first one was chosen for further investigation.

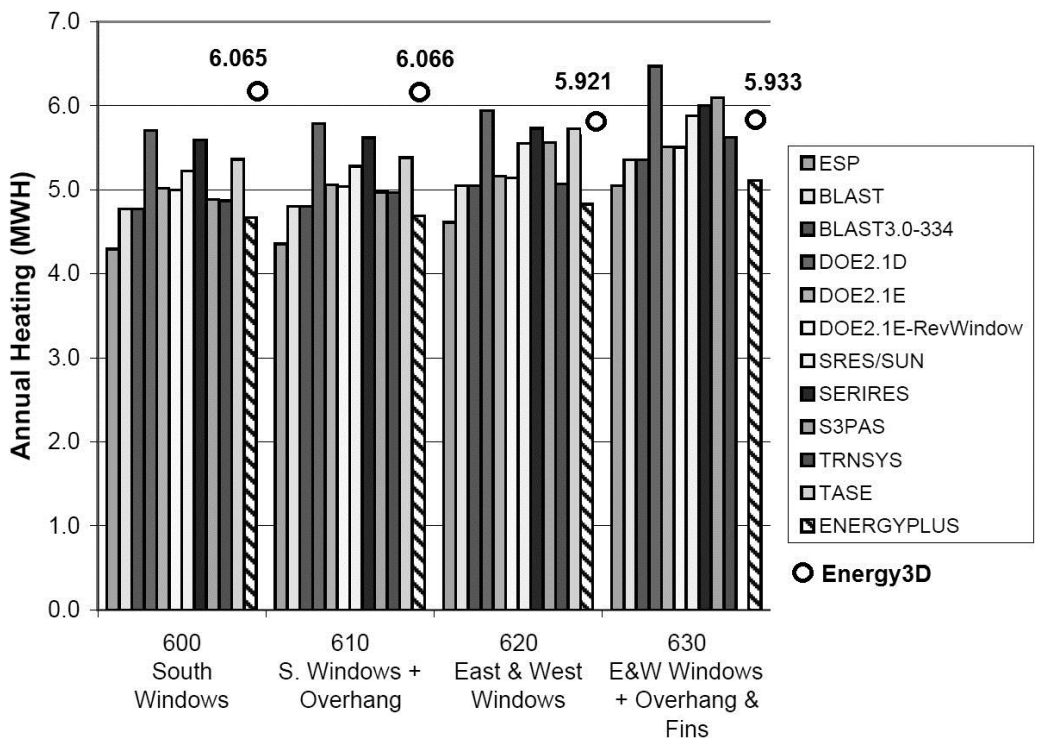

Fig. 6. Comparison of results for Denver

\section{CHOICE OF SOFTWARE}

The first program used in comparison is called Energy 3D. It is, as described by its creators, "a simulation-based engineering tool for designing green buildings and power stations that harness 
renewable energy to achieve sustainable development. At the end of the design, Energy3D allows users to print it out, cut out the pieces, and use them to assemble a physical scale model. Energy3D has been primarily developed to provide a simulated environment for engineering design (SEED) to support science and engineering education and training. As its simulation results are accurate and its user interfaces are friendly, it may also be used as an entry-level energy simulation tool for professionals."

Energy3D can be used for both qualitative and quantitative analysis. One can measure and compare:

- Effects of the house size on the energy use;

- Effects of the house shape on the energy use;

- Effects of roof insulation on the energy use of a house;

- Effects of roof color on the energy use of a house;

- Effects of solar heat gain coefficients of windows on the energy use of a house;

- Effects of orientation on the energy use of a house;

- Effects of the thermostat setting on the energy use of a house;

- Energy use of a house at different locations;

- Effects of environment albedo on the energy use of a house.

The second program used in comparison is called Energy Plus. It is described on its webpage in the following way: "EnergyPlus ${ }^{\mathrm{TM}}$ is a whole building energy simulation program that engineers, architects, and researchers use to model both energy consumption - for heating, cooling, ventilation, lighting and plug and process loads - and water use in buildings". It gives unlimited possibilities of modelling buildings energy performance, designing and optimizing HVAC (Heating, Ventilation, Air Conditioning) systems including sophisticated schedules, different purposes of particular zones, different heat/cool/electricity sources including renewables like photovoltaics, wind turbines, solar collectors etc., various occupancy profiles including differences even in gender of occupants.

EnergyPlus is a freeware tool funded by United States Government and probably because of that its interface is very poor and difficult in use. Various commercial software developers sell applications that allow user to easily model buildings of any shape and purpose, perform simulations and analyze results. One of these is DesignBuilder which was used in these comparisons.

DesignBuilder allowed to include all of assumptions listed in BESTEST 600 case building requirements such as all windows parameters (thickness of all glazing layers, parameters of filling gas, solar heat gain coefficient, etc.), an exact ventilation rate (using mechanical air handling unit with no heat recovery no recirculation and no humidity control), internal gains, etc. All assumptions are described in detail in [10]. 


\section{COMPARISON OF COMPUTATIONS}

Authors performed simulations in both programs in order to compare results and show potential sources of differences. Two Polish cities Wrocław (WRO) and Białystok (BIA) were chosen because of relatively big differences in their climate.

\subsection{ENERGY 3D}

Analysis in Energy 3D was performed for Wrocław and Białystok climate data. Temperature setpoint was set to $20^{\circ} \mathrm{C}$, which was used for both heating and cooling. Such assumption is far from common normative guidelines - according to PN-EN 15251 in residential buildings acceptable temperature for cooling season is $27^{\circ} \mathrm{C}$. Geometry and thermal insulation parameters were set according to the BESTEST 600 case building requirements.

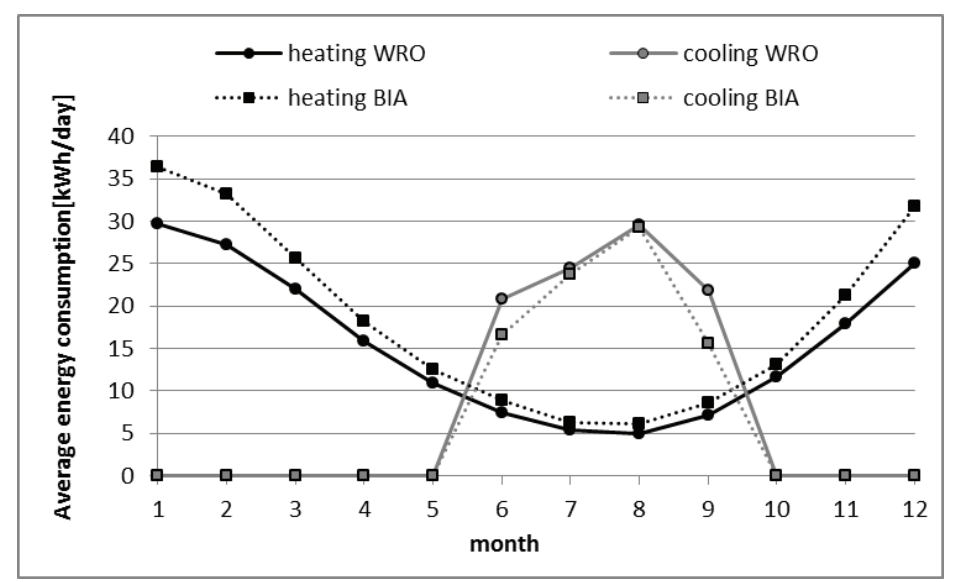

Fig. 7. Energy consumption per day for sample building located in Białystok and Wrocław

Results presenting energy use of a house at different locations are included in Fig. 7. Differences in climate in Poland are relatively small but annual energy for Białystok and Wrocław differ significantly which proofs that even not significantly diverse data (Energy 3D allows user to perform simulations in locations all around the world) let user to perform qualitative analysis. This proves correctness of the Energy 3D algorithm. 


\subsection{ENERGY PLUS (DESIGN BUILDER)}

Calculations were performed for the same two locations - Wrocław and Białystok. It is easy to see that assumptions used, especially constant heat gains and air change rate, caused overheating also in heating season (see Fig. 8), while Energy 3D automatically switched cooling off in months with dominating heating consumption. Energy $3 \mathrm{D}$ assumption has reflection in real buildings performance, because users prevent residential zones from overheating by, for example, opening windows. This is obviously the least efficient way. Modern ventilation systems are most often supplied with humidity control which automatically adjust fresh air stream to occupancy and usage profile.

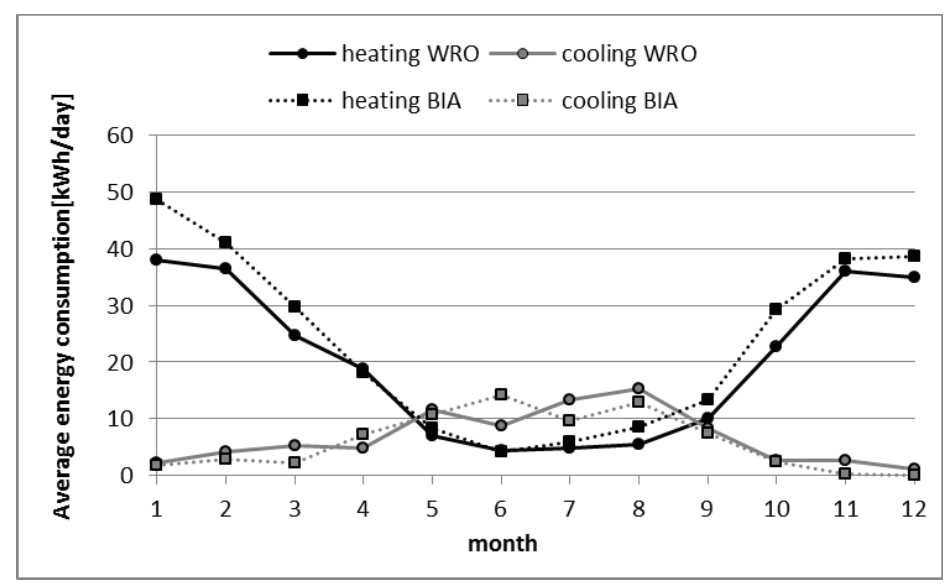

Fig. 8. Comparison of average daily energy consumption.

Possibility of performing calculations for any, even the most abstract solution, is a big advantage of EnergyPlus that allows to search for the best solutions, for example in Building Management Systems (BMS). Simplified methods based on monthly data, widely used in energy audits or designing Heat Ventilation Air Conditioning (HVAC) systems, are unable to highlight such fine adjustments.

Another advantage of the EnergyPlus code is possibility of performing analysis with different time steps - sub-hour, hour, day, week, month or only year. Such capability is highly useful in modelling dynamic simulation especially in buildings with significantly varying occupation schedules, like offices, shopping malls, laboratories, lecture halls etc. Weekly and hourly results are presented in such a way that energy for cooling has negative values to separate them on graph from heating energy consumption. Comparison of annual energy consumption is presented in Table 2. 
Table 2. Comparison of annual energy consumption results.

\begin{tabular}{|c|c|c|c|c|c|}
\hline $\begin{array}{c}\text { Heating } \\
\text { cooling }\end{array}$ & City & units & Energy 3D & $\begin{array}{c}\text { EnergyPlus } \\
\text { (DesignBuilder) }\end{array}$ & Difference \\
\hline Heating & Wrocław & {$[\mathrm{kWh} / \mathrm{a}]$} & 5636 & 7223 & $22 \%$ \\
\hline Heating & Białystok & {$[\mathrm{kWh} / \mathrm{a}]$} & 6753 & 8457 & $20 \%$ \\
\hline Cooling & Wrocław & {$[\mathrm{kWh} / \mathrm{a}]$} & 2940 & 2551 & $15 \%$ \\
\hline Cooling & Białystok & {$[\mathrm{kWh} / \mathrm{a}]$} & 2590 & 2256 & $15 \%$ \\
\hline
\end{tabular}

\section{WIENERBERGER HOUSE E4}

In the last stage of the project a real building - Wienerberger e4 House was investigated (see Fig. 9). The term e4 summarizes its four major features:

- Energy (minimizing energy losses, recuperation - recovering thermal energy, obtaining energy from renewable sources)

- Ecology (use of ecological building materials in order to create a favourable microclimate inside the house, use of renewable energy sources to produce electricity, heat home and hot water, what eliminates harmful emissions $\mathrm{CO}_{2}$.)

- Economy (design and construction consistent with the Polish financial realities, predictable operating costs, reasonable level of energy expenses.)

- Emotions (minimalist architecture that meets the expectations of customers, the use of materials that ensure safety, functional layout and unique design.) 


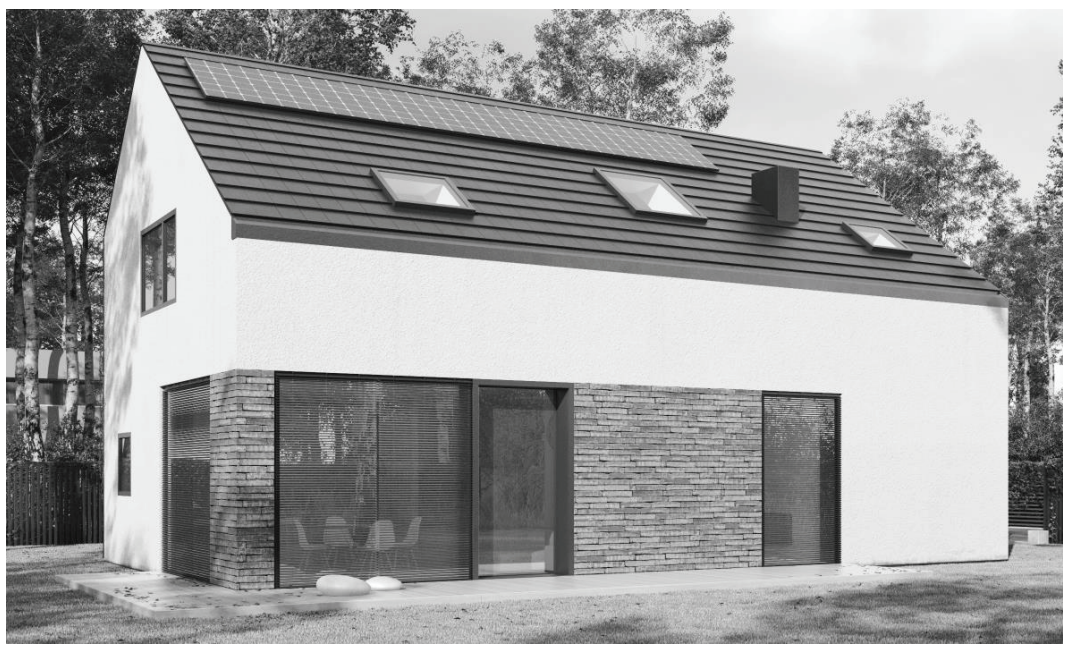

Fig. 9. e4 house (source: http://dome4.pl)

Total area of the house is $147.1 \mathrm{~m}^{2}$ (see Fig. 10). Calculations of monthly energy consumption were performed by National Agency for Energy Conservation (NAPE). Data for these calculations are presented in Table 3.
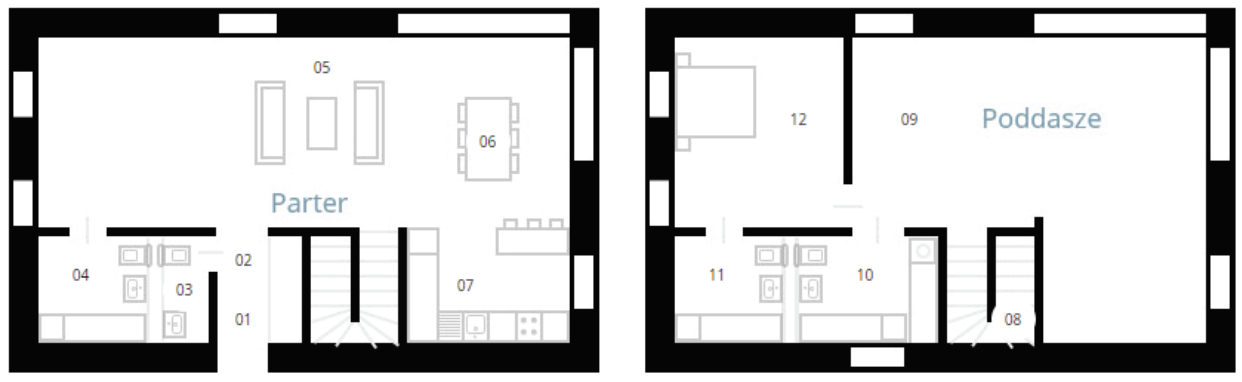

Fig. 10. Plans of floors of e4 house. (source: http://dom4e.pl)

Table 4.Thermal data for e4 House.

\begin{tabular}{|c|c|}
\hline Element & $\begin{array}{c}\mathbf{U} \\
{\left[\mathbf{W} / \mathbf{m}^{2} \mathbf{K}\right]}\end{array}$ \\
\hline Walls & 0.162 \\
\hline Foundation & 0.127 \\
\hline Roof & 0.092 \\
\hline
\end{tabular}




\begin{tabular}{|l|l|}
\hline Windows & 0.900 \\
\hline
\end{tabular}

Next computations were performed by means of Energy 3D code. Simplified model is presented in Figure 11 .

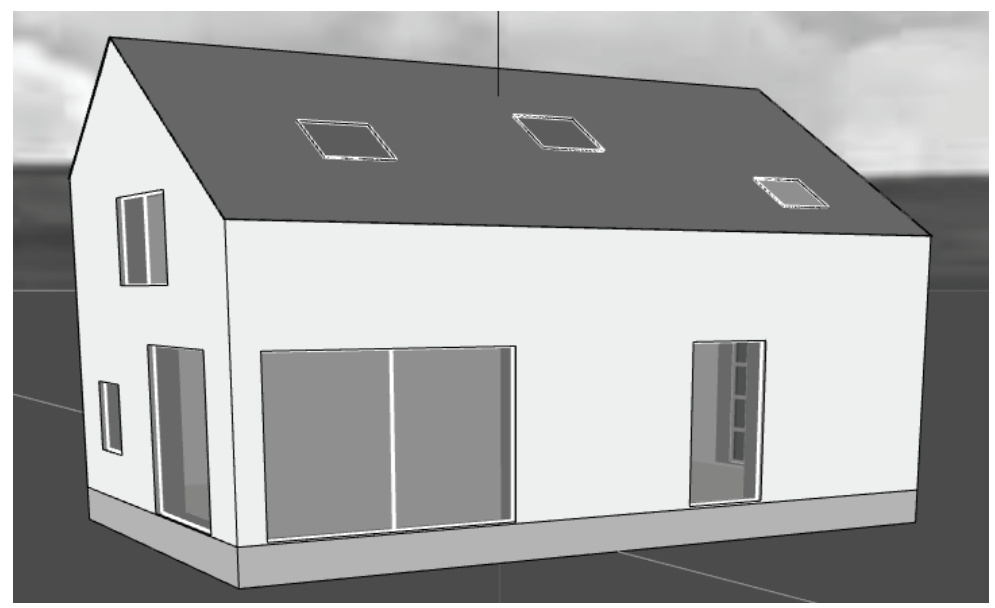

Fig. 11. Simplified model of e4 House.

Comparison of results is presented in Table 4.

Table 4. Comparison of results for heating for e4 House.

\begin{tabular}{|c|c|c|c|}
\hline Month & $\begin{array}{c}\text { EnergyPlus } \\
{[\mathbf{k W h}]}\end{array}$ & $\begin{array}{c}\text { Energy 3D } \\
{[\mathbf{k W h}]}\end{array}$ & Difference \\
\hline November. & 637 & 672 & $-5.49 \%$ \\
\hline December & 1062 & 1009 & $5.04 \%$ \\
\hline January & 1093 & 1070 & $2.10 \%$ \\
\hline February & 697 & 789 & $-13.21 \%$ \\
\hline
\end{tabular}

Difference of results for December and January is very small - results from both programs are nearly the same. For other two months differences are bigger due to the fact that in these months there are more sunny hours. Difference for February is higher than in November because February is more sunny than November. 


\section{DISCUSSION OF RESULTS}

The basic difference between Energy Plus (DesignBuilder) and Energy 3D mentioned above is flexibility of these two codes. Energy 3D uses a lot of assumptions that are not modifiable by user, for example:

- rate of air change per hour;

- type of ventilation and heating system;

- schedules of heating and cooling setpoints;

- values of the thermal-bridges coefficients.

Furthermore, results revealed that Energy 3D does not take temperature setpoint for cooling calculations, because annual consumption result was lower in the Energy 3D model than in EnergyPlus with a cooling temperature setpoint at $27^{\circ} \mathrm{C}$.

This paper is an extended version of [6], [7] where only selected results were shown. Comparison performed and presented above proved that Energy 3D is a useful software in quantitative analysis, able to estimate an expected order of magnitude in energy consumption for heating and cooling in residential building. Its simplicity, variety of template models and built-in options, enabling users to perform simplified topological optimization, should find wide credit in real estate market of residential buildings as a helpful tool for buyers even with basic knowledge in building physics. However, deep qualitative research is not possible with this software due to its poor access to significant calculation methods from user's interface. Comparison with EnergyPlus based computations proved that, even for the simplest test case of BESTEST 600 building, the results for both heating and cooling for the whole year are significantly different while EnergyPlus is valued benchmark for such simulations. On the other hand, while taking into account only "winter months", difference in results for real world building - Wienerberger e4 House - are very small.

This work was partly supported by the NCBiR grant number POIG.02.03.01-14-026/13.

\section{REFERENCES}

1. M. Baratieri, F. Patuzzi, A. Gasparella, V. Corrado, eds., Building Simulation Applications BSA 2015, Bozen-Bolzano University Press, 2015.

2. J. Clarke, Energy Simulation in Building Design, Second Edition, 2 edition, Butterworth-Heinemann, Oxford, 2001.

3. D. Coakley, P. Raftery, M. Keane, "A review of methods to match building energy simulation models to measured data" Renewable and Sustainable Energy Reviews. 37: 123-141 (2014).

4. B. Delcroix, M. Kummert, A. Daoud, M. Hiller, "Improved Conduction Transfer Function Coefficients Generation in TRNSYS Multizone Building Model” in: Proceedings of BS2013, Chambéry, France, 2013: pp. 2667-2674. 
5. N. Fumo, "A review on the basics of building energy estimation" Renewable and Sustainable Energy Reviews. 31: 53-60 (2014).

6. R. Gajewski, P. Pieniążek, "Building energy modelling and simulations: qualitative and quantitative analysis" MATEC Web of Conferences. 117: 00051 (2017).

7. R.R. Gajewski, T. Kułakowski, P. Pieniążek, "Building energy software: comparison of Energy 3D and Energy Plus computations" in: S. Jemioło, A. Al Sabouni-Zawadzka (Eds.), Theoretical Foundation of Civil Engineering. Mechanics of Structures, Warsaw University of Technology, 2018: pp. 65-76.

8. M.H. Goldstein, Ş. Purzer, R.S. Adams, J. Chao, C. Xie, "The relationship between design reflectivity and conceptions of informed design among high school students" European Journal of Engineering Education. 0: 1-14 (2018).

9. V.S.K.V. Harish, A. Kumar, "A review on modeling and simulation of building energy systems" Renewable and Sustainable Energy Reviews. 56: 1272-1292 (2016).

10. R. Henninger, M. Witte, EnergyPlus Testing with ANSI/ASHRAE Standard 140-2001 (BESTEST) EnergyPlus Version 1.2. 1.012, Ernest Orlando Lawrence Berkeley National Laboratory, Berkeley, California, 2004.

11.J.L.M. Hensen, R. Lamberts, eds., Building Performance Simulation for Design and Operation, Routledge, London ; New York, 2011.

12.R. Judkoff, J. Neymark, International Energy Agency building energy simulation test (BESTEST) and diagnostic method, National Renewable Energy Laboratory, Golden, Coloradu, US, 1995.

13.R. Judkoff, J. Neymark, "Twenty years on!: updating the IEA BESTEST building thermal fabric test cases for ASHRAE standard 140" in: Proceedings of BS2013, Chambery, France, 2013: pp. 63-70.

14. R. Judkoff, B. Polly, M. Bianchi, J. Neymark, "Building Energy Simulation Test for Existing Homes (BESTEST-EX) Methodology" in: Proceedings of Building Simulation 2011, 185-192, Sydney, Australia, 2011.

15.D. Kuzmin, J. Hamalainen, Finite Element Methods for Computational Fluid Dynamics: A Practical Guide, SIAM, 2014.

16.T. Maile, Comparing Measured and Simulated Building Energy Performance Data, Doctor of Philosophy Thesis, Stanford University, 2010.

17.T. Maile, V. Bazjanac, M. Fischer, "A method to compare simulated and measured data to assess building energy performance" Building and Environment. Complete: 241-251 (2012).

18.P. Narowski, M. Mijakowski, J. Sowa, "Integrated calculations of thermal behavior of both buildings and ventilation and air conditioning systems" in: S. Santanam, E.A. Bogucz, C. Peters, T. Benson (Eds.), Proceedings of the 9th International Healthy Buildings Conference and Exhibition, International Society of Indoor Air Quality and Climate, Syracuse, NY, USA, 2009: pp. 1683-1686.

19.P. Nithiarasu, R.W. Lewis, K.N. Seetharamu, Fundamentals of the Finite Element Method for Heat and Mass Transfer, 2 edition, Wiley, Chichester, West Sussex, 2016.

20.P. Pieniążek, Computer Simulation of Building Energy, B.Sc. Thesis, Warsaw University of Technology, Faculty of Civil Engineering, 2016.

21.T.A. Reddy, "Literature Review on Calibration of Building Energy Simulation Programs: Uses, Problems, Procedures, Uncertainty, and Tools" ASHRAE Transactions; Atlanta. 112: 226-240 (2006).

22.A.F. Robertson, D. Gross, “An Electrical-Analog Method for Transient Heat-Flow Analysis” Journal of Research of the National Bureau of Standards. 61: 105-115 (1958).

23.C. Rode, R. Peuhkuri, M. Woloszyn, "Simulation tests in whole building heat and moisture transfer" in: Research in Building Physics and Building Engineering, Taylor \& Francis Group, Montreal, Canada, 2006: pp. 527-534.

24.T. Soubdhan, T.A. Mara, H. Boyer, A. Younès, "Use of BESTEST procedure to improve a building thermal simulation program" in: Renewable Energy. Renewables: The Energy for the 21st Century, Elsevier, Brighton, GB, 2000: pp. $1800-1803$

25.D.G. Stephenson, G.P. Mitalas, “Calculation of heat conduction transfer functions for multi-layer slabs" ASHRAE Transactions. 77: 117-126 (1971).

26.J. Tu, G. Heng, C. Liu, Computational Fluid Dynamics: A Practical Approach, 2 edition, Butterworth-Heinemann, Amsterdam, 2012.

27.C. Underwood, F. Yik, Modelling Methods for Energy in Buildings, 1 edition, Wiley-Blackwell, Oxford; Malden, MA, 2004

28.H. Versteeg, W. Malalasekera, An Introduction to Computational Fluid Dynamics: The Finite Volume Method, 2 edition, Pearson, Harlow, England ; New York, 2007.

29. M. Woloszyn, C. Rode, Modelling principles and common exercises - final report, International Energy Agency, 2007.

30.C. Xie, C. Schimpf, J. Chao, S. Nourian, J. Massicotte, "Learning and teaching engineering design through modeling and simulation on a CAD platform" Computer Applications in Engineering Education. 26: 824-840 (2018).

31.H.Z. Zhang, C. Xie, S. Nourian, "Are their designs iterative or fixated? Investigating design patterns from student digital footprints in computer-aided design software" International Journal of Technology and Design Education. 28: 819-841 (2018). 


\section{LIST OF FIGURES AND TABLES:}

Fig. 1. Cross section of the analysed structure.

Rys. 1. Przekrój analizowanej konstrukcji.

Fig. 2. a) T1 temperature raise case; b) T2 temperature raise case

Rys. 2. a) Przypadek wzrostu temperatury T1; b) Przypadek wzrostu temperatury T2.

Fig. 3. Heat flux on surface 1 after temperature raise on: a) surface 1 b) surface 2 .

Rys. 3. Strumień ciepła na powierzchni 1 po wzroście temperatury na: a) powierzchni 1; b) powierzchni 2.

Fig. 4. Temperature unit load.

Rys. 4. Jednostkowe obciążenie temperature.

Fig. 5. BESTEST case building 600.

Rys. 5. BESTEST - przykładowy budynek 600.

Fig. 6. Comparison of results for Denver

Rys. 6. Porównanie wyników dla Denver.

Fig. 7. Energy consumption per day for sample building located in Białystok and Wrocław

Rys. 7. Dzienne zużycie energii dla przykłądowych budynków w Białymstoku i Wrocławiu.

Fig. 8. Comparison of average daily energy consumption.

Rys. 8. Porównanie średniego dziennego zużycia energii.

Fig. 9. e4 house (source: http://dome4.pl)

Rys. 9. Dom e4 (żródło: http://deme4.pl)

Fig. 10. Plans of floors of e4 house. (source: http://dom4e.pl)

Rys. 10. Plany parteru I piętra domu e4 (źródło: http://dome4.pl)

Fig. 11. Simplified model of e4 House.

Rys. 11. Uproszczony model domu e4.

Tab. 1. Wall Construction (light weight mass).

Tab. 1. Konstrukcja ściany lekkiej.

Tab. 2. Comparison of annual energy consumption results.

Tab. 2. Porównanie wyników rocznego zużycia energii.

Tab. 3. Thermal data for e4 House.

Tab. 3. Dane cieplne domu e4.

Tab. 4. Comparison of results for heating for e4 House.

Tab. 4. Porównanie wyników dla ogrzewania domu e4. 


\section{W KIERUNKU PROJEKTOWANIA BUDYNKÓW EFEKTYWNYCH ENERGETYCZNIE}

Slowa kluczowe: budynki efektywne energetycznie, symulacja, weryfikacja, walidacja, MES, MRS

\section{STRESZCZENIE :}

W związku ze znaczącym udziałem budynków w globalnym zapotrzebowaniu na energię ich projektowanie staje się coraz bardziej ukierunkowane na efektywne wykorzystanie nieodnawialnych zasobów takich jak np. paliwa kopalne. Celem niniejszej publikacji jest prezentacja możliwości jakie daje wykorzystanie oprogramowania do symulacji energetycznych budynków przy ich projektowaniu. We współpracy z firmą Wienerberger, która udostępniła dane dotyczące ich budynku modelowego oraz wyniki symulacji przeprowadzonych przez Narodową Agencję Poszanowania Energii S.A w ramach optymalizacji jego projektu, autorzy porównali możliwości przykładowych, dostępnych komercyjnie narzędzi symulacyjnych - Energy3D oraz EnergyPlus (Design Builder) oraz porównali z wynikami benchmarkowymi na przykładzie budynku BESTEST. Poza omówieniem założeń obliczeniowych, a także dostępnych funkcjonalności programów, niniejszy artykuł zawiera streszczenie zagadnień wymagających rozwiązania przy symulacjach dynamicznej wymiany ciepła $\mathrm{w}$ budynkach oraz wybrane metody obliczeniowe stosowane w komercyjnych programach komputerowych.

Porównanie wyników uzyskiwanych dla budynków BESTEST pokazało, że program Energy3D dostępny na zasadzie licencji freeware, daje wyniki symulacji zbliżone do narzędzi opartych np. o silnik Energy Plus, sprzedawanych na zasadach komercyjnych.

Symulacje sezonowego zapotrzebowania na energię do celów grzewczych oraz chłodniczych w budynku modelowym przeprowadzono dla dwóch miast w Polsce - Wrocławia i Białegostoku. Taki dobór spowodowany był faktem, iż wspomniane lokalizacje prezentują skrajne, jak na warunki polskie, charakterystyki meteorologiczne. Porównanie pokazało, że uzyskane dla tego samego budynku, przy pomocy różnych narzędzi symulacyjnych wyniki prezentują znaczące różnice. Autorzy podjęli próbę wskazania przyczyny takiego stanu rzeczy i w tym celu przeprowadzili symulacje godzinowe w obydwu programach, a następnie porównali wyniki w miesiącach zimowych. Analiza pozwoliła na potwierdzenie stawianej tezy, iż program Energy 3D nie odstaje od innych dostępnych kodów pod kątem jakości obliczeń, jednak nie pozwala na ingerencję użytkownika w tak dużą liczbę warunków brzegowych jak program oparty na silniku EnergyPlus, co jest bezpośrednią przyczyną rozbieżności w wynikach symulacji rocznych. 